\title{
O suspense na obra literária e na série de streaming, o conto da aia pelo olhar da estética da recepção
}

\section{The suspense in the handmaid's tale in the light of the aesthetic of reception}

DOI: $10.46814 / \operatorname{lajdv3n6-015}$

Recebimento dos originais: 01/10/2021

Aceitação para publicação: 25/11/2021

Jaynne Silva de Sousa Borges

Mestranda em Letras pela Universidade Federal do Maranhão

E-mail: jaynneborges96@gmail.com

\begin{abstract}
Naiara Sales Araújo
Doutora em Literatura Comparada pela Universidade Metropolitana de Londres e Professora do Mestrado acadêmico em Letras da Universidade Federal do Maranhão

E-mail: naiara.sas@ufma.br
\end{abstract}

\section{RESUMO}

Este artigo objetiva analisar os efeitos do suspense na obra literária $O$ conto da aia (1985), de Margaret Atwood, e na primeira temporada da série de streaming homônima, adaptada desse livro, de autoria de Bruce Miller. Para isso, será utilizada a teoria da Estética da Recepção como norteadora para a investigação das relações entre obra (literária ou audiovisual), autor e receptor, com enfoque na participação dos destinatários enquanto figuras centrais para a significação artística. Assim, foram selecionadas algumas cenas em que é utilizada a ferramenta cliffhanger, ou momento de conflito, para discutir a utilização desse recurso de tensão e consequente empolgação do leitor/telespectador. Notase, enfim, que os momentos de suspense são um artifício que contribui para o sucesso de recepção da série, ao passo que podem causar uma quebra de expectativas para leitores que buscam o livro após assistir ao seriado.

Palavras-chave: Suspense, Literatura, Série de Streaming, Estética da Recepção.

\begin{abstract}
This article aims to analyze the effects of suspense in the literary work The Handmaid's Tale (1985), by Margaret Atwood, and in the first season of the homonymous streaming series adapted from that book, The Handmaid's Tale (2017), by Bruce Miller. To this, the theory of aesthetics of reception will be used as a guide to the investigation of relationships between works (be it literary or audiovisual), author and receiver, with a focus on the participation of recipients as central figures for artistic significance. Thus, were selected some scenes that use cliffhangers, or moments of conflict, to discuss the use of this tension instrument and the consequent excitation of the reader/viewer. It is notice, then, that the moments of suspense are an artifice that contributed to the success of the series reception, while they can cause a break of expectations for readers who seek the book after watching the show.
\end{abstract}

Keywords: Suspense, Literature, Streaming series, Reception aesthetics. 


\section{INTRODUÇÃO}

A noção de suspense, no que se refere a produções fictícias, está geralmente atrelada a obras que remetem ao medo, ao terror, relacionados a um contexto sobrenatural ou à violência mais realista. Contudo, em produções de tipos diversos, o suspense se configura como uma ferramenta de atração para o receptor, voltando-se para o medo do que vem a seguir, mas principalmente causa expectativa, muitas vezes esperançosa por parte do leitor/telespectador.

O gênero ficção distópica abarca variadas características que se conectam com a ideia do suspense, de certo modo. Usualmente, o romance distópico apresenta sociedades semelhantes às já existentes ou que já existiram, mas que vivem num cenário cujas dificuldades são acentuadas. Assim, é comum que nessas obras haja governos totalitários, que monitoram a todos, falta de liberdade, violência exacerbada, desigualdade social e injustiças. Logo, o medo é comum nessas histórias, mas o suspense não se faz presente necessariamente, a menos que seja uma ferramenta de conflito e de mudança da situação.

Nesse sentido, a partir da leitura e acompanhamento de algumas produções de ficção distópica - como 1984 (1949), de George Orwell; Fahrenheit 451 (1953), de Ray Bradbury; Jogos Vorazes (2008), de Suzanne Collins, dentre outras -, nota-se o suspense como artifício de moção nessas histórias, que, a partir da quebra da "normalidade", promovida pelos protagonistas e outros personagens, levam o leitor/telespectador a acompanhar o que acontece, na dúvida e curiosidade do que está por vir e, principalmente, na esperança de que o(a) mocinho(a) se livre dos conflitos, das dificuldades e consiga vencer o sistema ou parte dele.

Dadas essas informações, percebe-se que a série $O$ conto da aia, criada por Bruce Miller, tem cultivado grande popularidade desde o ano de seu lançamento, em 2017, até atualmente, já na quarta temporada e com catorze prêmios e outras inúmeras indicações. Consequentemente, a procura pela obra que inspirou a história, O conto da aia (1985), de autoria de Margaret Atwood, também cresceu, algo que pode ser relacionado ainda aos recentes contextos políticos protagonizados principalmente pelos governos conservadores de alguns países.

Muitos podem ser os motivos para o sucesso de $O$ conto da aia (2017), mas supõe-se que a relação do público com a série é um dos principais. A utilização do suspense para prender a atenção dos telespectadores a continuarem assistindo, acompanhando e desvendando o desenrolar da história pode ser considerada uma estratégia distintiva, visto que o formato utilizado é o de liberar um episódio por semana para os lançamentos. Todavia, mesmo para as temporadas já finalizadas, o suspense ainda funciona como motor para que os espectadores continuem consumindo a série.

Quanto à obra literária $O$ conto da aia, cabe apontar que se configura de maneira reflexiva, podendo ser considerada uma narrativa mais arrastada e parada. O suspense também está presente, mas 
não da mesma maneira. Porém, o objetivo deste artigo não é comparar as duas produções quanto à utilização desse recurso de expectativa, nem determinar se a adaptação é melhor que a obra original, ou vice-versa; considera-se que as duas obras são igualmente relevantes, cada uma à sua maneira e com suas diferentes características. Por isso, este trabalho pretende investigar o uso do suspense em ambas e a relação desse recurso com o público.

Assim, para analisar a construção e os efeitos do suspense em $O$ conto da aia (1985) e na adaptação homônima de 2017, recortou-se a primeira temporada da série, pelo fato de ser a mais inspirada na obra literária, já que as temporadas seguintes tomam rumos independentes e novos, isto é, para além da obra original. Além disso, o estudo foi realizado a partir de algumas cenas de conflito e suspense, como finais de capítulos do livro e cenas finais dos episódios da série. Ademais, a análise é baseada em produções recentes sobre a Estética da Recepção, especialmente voltada para a importância do público da literatura e de produções audiovisuais.

Deste modo, as seções a seguir introduzem algumas noções necessárias sobre essa teoria, além de algumas definições sobre o cliffhanger (mecanismo de suspense) e outras discussões necessárias sobre séries de streaming e relações com a literatura. Esses apontamentos, vale ressaltar, são articulados nas seções posteriores de análise do livro e da série e, finalmente, as considerações finais respondem aos questionamentos que permeiam esse estudo, promovendo, ainda, uma reflexão para pesquisas futuras.

\section{ALGUNS APONTAMENTOS SOBRE A ESTÉTICA DA RECEPÇÃO}

Trabalhar obras artísticas sob a perspectiva da recepção caracteriza certo rompimento de estruturas convencionadas em que importa apenas estudar o objeto em si ou relacionado ao contexto e ao autor. Compreender o leitor/espectador/receptor da produção como principal agente nesse conjunto, o qual significa e move as intenções do autor e a materialização da criação dele - a obra - é uma maneira de aproximar o texto do público e de retomar a ideia central da realização cultural: o produto é do povo, e não apenas da parte mais culta deste. É nesse sentido que se aplicam as considerações da teoria da Estética da Recepção, em que, segundo a pesquisadora Cristiane Navarrete Tolomei:

[...] o leitor ganha um papel ativo e passa a ser um elemento reestruturante na escrita da obra pelo autor. De acordo com Hans Robert Jauss (1979), a relação texto-leitor passa a constituir um caráter fundamental do fato literário, pois para o teórico a obra literária não pode ser concebida sem a participação ativa de seu leitor, recuperando a historicidade da literatura e restabelecendo a relação, rompida pelo historicismo, entre o passado e o presente. (JAUSS, 1979 apud TOLOMEI, 2017, p. 161)

Assim, pela visão de Jauss, citado acima, o leitor - considerando o texto literário, por mais que a área se aplique a outras formas de arte - tem papel de continuidade na história da obra, renovando 
sua importância com o passar do tempo e, de certa forma, propagando-a com outros leitores. Hans Robert Jauss é, aliás, um dos grandes nomes dessa teoria, cujos textos introdutórios contribuem para a presente pesquisa, como é o caso de "A estética da recepção: colocações gerais". Em tal texto, Jauss apresenta a proposta dos estudos da Estética da Recepção, declarando que

[a] experiência estética não se inicia pela compreensão e interpretação do significado de uma obra; menos ainda, pela reconstrução da intenção de seu autor. A experiência primária de uma obra de arte realiza-se na sintonia com (Einstellung auf) seu efeito estético, isto é, na compreensão fruidora e na fruição compreensiva. Uma interpretação que ignorasse esta experiência estética primeira seria própria da presunção do filólogo que cultivasse o engano de supor que o texto fora feito, não para o leitor, mas sim, especialmente, para ser interpretado. (JAUSS, 2011a, p. 69)

Ou seja, na leitura de uma produção artística existe a combinação da interpretação com o prazer, que formam um processo único, em que nem texto, nem leitor se sobressaem um ao outro, mas possuem igual importância, e nisso também se insere o trabalho do autor, que tem a função dupla de produzir pela obra e pelo receptor. Visto por esse ângulo, esse parece um procedimento complicado, mas é natural, separado assim apenas para se poder compreender como a recepção de uma obra artística está envolta em uma complexa teia de agentes e produtos.

Nesse sentido, Jauss (2011a) defende a necessidade de entender a recepção, considerando-se que esta possui dois lados, os quais precisam ser trabalhados: o primeiro, voltado para o efeito e significado dos receptores contemporâneos; o segundo, atrelado ao processo histórico de recepção diversificado. É na comunicação entre essas duas informações que a Estética da Recepção é concebida enquanto paradigma para um estudo que circunda as incontáveis possibilidades de resultados das relações entre autor-obra-leitor. Logo,

[...] para a análise da experiência do leitor ou da "sociedade de leitores" de um tempo histórico determinado, necessita-se diferenciar, colocar e estabelecer a comunicação entre os dois lados da relação texto e leitor. Ou seja, entre o efeito, como o momento condicionado pelo texto, e a recepção, como o momento condicionado pelo destinatário, para a concretização do sentido como duplo horizonte - o interno ao literário, implicado pela obra, e o mundivivencial (lebensweltlich), trazido pelo leitor de uma determinada sociedade. (JAUSS, 2011a, p. 73)

Apreende-se, assim, que nessa relação de leitura estão inseridos sentidos intraliterários que vêm da materialidade textual e sentidos contextuais motivados pela vivência do leitor/espectador. Isso compreende, por conseguinte, uma movimentação que vem tanto do texto quanto do receptor, cuja junção resulta numa significação mescla e multifacetada. Para mais, evidencia as qualidades das produções artísticas enquanto meios essenciais para a existência humana, com contribuições informativas e contemplativas, ou seja, consumir obras artísticas - sejam livros, filmes, séries, etc. - 
não só atribui novos conhecimentos para os indivíduos, mas também são formas de prazer e reflexão. É o que atesta Tolomei, ao dizer que

Jauss insiste sobre a natureza emancipatória da arte literária, acreditando que, de algum modo, ela subtraia o indivíduo de seu estado de solidão, ampliando suas perspectivas. Para o autor, a literatura confere uma importância social que vai muito além do papel reprodutor, ele reconhece a relação texto-leitor como uma "comunicação dialógica" em que o signo linguístico induz o receptor a comportar-se de determinada maneira, embora reconheça também que isso é antes um convite que uma ordem, cabendo a escolha ao receptor. (TOLOMEI, 2017, p. 162)

Quanto à escolha do leitor, mencionada logo acima, Jauss também justifica que a experiência da recepção não é totalmente comandada por influências externas; elas têm, sim, sua participação nesse processo, dado que o contexto está ligado diretamente à vivência do público. Porém, ainda prevalece a escolha do leitor/espectador, porque o consumo e contemplação de qualquer produção artística compreende a atividade da percepção e o processamento do conteúdo:

É só de modo parcial que a necessidade estética é manipulável, pois a produção e a reprodução da arte, mesmo sob as condições da sociedade industrial, não conseguem determinar a recepção: a recepção da arte não é apenas um consumo passivo, mas sim uma atividade estética, pendente da aprovação e da recusa, e, por isso, em grande parte não sujeita ao planejamento mercadológico. (JAUSS, 2011a, p. 80)

Isto posto, nota-se que apesar de envoltos por um cenário de certo modo manipulador e controlador dos produtos artísticos - e mais ainda dos consumidores -, os autores são capazes de criar o que quiserem; suas produções podem ter múltiplos efeitos e o público tem a liberdade de gostar ou não do que veem, leem, assistem, escutam; afinal, segundo o trecho acima, nenhum desses processos nem as consequências destes são previsíveis, dado que correspondem a infinitas combinações de decisões, pontos de vista e interpretações.

Outro texto de Jauss, “O prazer estético e as experiências fundamentais da Poiesis, Aisthesis e Katharsis", fornece maiores explicações sobre as ligações entre estética e prazer e ainda as três categorias da fruição estética. Esse autor diferencia o prazer estético do normal devido à tomada de posição do receptor e consequente transformação do objeto em objeto estético, em que o sujeito participa da produção dele através do imaginário, o que foge da entrega imediata, sentimental e desinteressada do prazer comum (JAUSS, 2011b). Tal participação não é distanciada, mas de entrega e recebimento recíprocos:

[...] o sujeito, enquanto utiliza sua liberdade de tomada de posição perante o objeto estético irreal, é capaz de gozar tanto o objeto, cada vez mais explorado por seu próprio prazer, quanto seu próprio eu, que, nesta atividade, se sente liberado de sua existência cotidiana. Por conseguinte, o prazer estético realiza-se sempre na relação dialética do prazer de si no prazer no outro [...]. (JAUSS, 2011b, p. 97-98) 
É um procedimento de entrega e imersão, então. E Jauss ainda soma a isso que o receptor não realiza um prazer de base unicamente própria, mas também inclui a experiência outra, bem como as múltiplas possibilidades de ser um sujeito diferente. Desse modo, ele parte para as categorias de fruição estética, que são a poiesis, a aisthesis e a katharsis. Jauss define-as basicamente, nessa ordem, como consciência produtora, consciência receptora e consciência transformadora, que podem ser resumidas em diferentes manifestações do prazer, de certa maneira. Vale lembrar que elas não são um conjunto hierárquico, e podem se combinar e transfigurar-se. (JAUSS, 2011b)

Expandindo essas noções, o teórico Wolfgang Iser, também pioneiro na teoria da Estética da Recepção, argumenta que a relação texto-leitor é como um "modo de criação do mundo", em que o texto deixa de ser a única origem do conteúdo para dividir esse encargo com o receptor. A preocupação de Iser não é produto dessa interação, mas o jogo entre autor-texto-leitor, que, segundo ele, não resulta em uma representação do mundo externo: esse sistema gera, na verdade, muitas diferenças (ISER, 2011). Ele explica, mais especificamente, que

[o]s autores jogam com os leitores e o texto é o campo do jogo. O próprio texto é o resultado de um ato intencional pelo qual um autor se refere e intervém em um mundo existente, mas, conquanto o ato seja intencional, visa a algo que ainda não é acessível à consciência. Assim o texto é composto por um mundo que ainda há de ser identificado e que é esboçado de modo a incitar o leitor a imaginá-lo e, por fim, a interpretá-lo. (ISER, 2011, p. 107)

Moldado, construído e reconstruído, esse novo mundo é formado por vários níveis de diferenças que, segundo Iser, ocorrem extratextualmente, ainda no processo de criação do autor, com o mundo extratextual e também com outros textos; intratextualmente, entre os itens baseados nos sistemas extratextuais e as possibilidades semânticas do texto; e entre texto e leitor, tanto nas decisões próprias do receptor como nas que são necessárias para a leitura, além do que o texto projeta com seu mundo novo e o que essa projeção quer provocar. (ISER, 2011)

São essas diferenças que põem o jogo em movimento e contribuem para a dualidade dele, porque, ao mesmo tempo em que ele remove as diferenças no trajeto para o encerramento, também tenta manter as diferenças ao restabelecer sua liberdade, continuidade e abertura (ISER, 2011). Afinal, o jogo do texto é um contínuo de combinações, um processo constante que se inicia ainda na criação do autor e sua obra, e que é sempre renovado conforme cada leitura e recepção. Esses raciocínios dão conta, de certo modo, da gama de procedimentos envolvidos na receptividade de um texto.

Assim sendo, na seção seguinte discute-se a respeito de adaptações como objetos individuais das obras-origem, justificação necessária por conta do caráter do presente trabalho, que analisa duas produções das quais uma delas é a adaptação da outra. 


\section{SOBRE TRADUÇÕES E ADAPTAÇÕES}

Os pensamentos reunidos anteriormente sobre a Estética da Recepção tratam muito sobre o texto. Para esclarecer, toma-se texto, neste artigo, não só como a produção literária, mas qualquer criação artística voltada para a ficção. Assim, dado o objetivo deste trabalho em analisar uma obra de literatura e uma produção audiovisual, é preciso destacar que a intenção não é compará-las, pois se considera que ambas são produções independentes e igualmente válidas para este estudo, não sendo necessário conhecê-las em conjunto para entender a história. É o que defende Tânia Franco Carvalhal (2000), no texto "De traduções, tradutores e processos de recepção literária", em que fala sobre as traduções em relação à recepção, ainda que sob a perspectiva literária e pela vertente da Literatura Comparada.

Carvalhal considera a importância de tomar a tradução - aqui entendida como a da categoria intersemiótica, como é o caso da adaptação do livro para a série - como um importante meio de disseminação artística, que deve ser estudada de maneira individual e também como parte do processo de transformação das formas, efeitos, gêneros e gosto, um material representativo de culturas e de outros textos (CARVALHAL, 2000). Ou seja, o produto adaptado é um novo produto, diferente, por vezes considerado melhor ou pior com base em diversos parâmetros, mas único.

Por mais que a intenção aqui não seja comparar ou equiparar o livro $O$ conto da aia e a série $O$ conto da aia, pelo olhar da Estética da Recepção, é inevitável analisar, como aponta Carvalhal logo acima, as transformações e diferentes efeitos causados por ambas no público, no que se refere especialmente ao uso do suspense. Nesse sentido, a autora supracitada destaca, ainda, a importância da tradução como mediadora do contato entre o leitor/receptor com uma obra com a qual este não tinha ou não pretendia ter acesso, ou seja, com a transformação de uma produção de um veículo para outro - por exemplo, o destinatário pode conhecer técnicas e formas diferentes, que podem ser renovadas, ressignificadas (CARVALHAL, 2000).

Em vista disso, é natural que, ao mesmo tempo em que as traduções facilitam o conhecimento e aproximam diferenças culturais, também determinam e são determinadas pelo trabalho do autor, que lhe dá nova forma e com ela influencia nas demais produções do meio artístico, buscando adequar o novo produto num contexto diferente, para um público possivelmente tão diferente quanto. "Tal é o sentido da tradução como resultado de um desejo, de uma escolha deliberada por parte do tradutor", afirma Tânia Carvalhal (2000, p. 92). Tradutor esse que é autor, ao considerar a tradução de um meio para outro.

Entende-se, assim, que adaptações também são obras originais, que não necessitam de apoio na produção-primeira para serem entendidas e estudadas. No caso do presente artigo, reitera-se que o uso do livro e da série é para compreender sobre o uso do suspense em ambos, de forma independente, mas 
traçando relações que se associem ao contexto de recepção do público. Dito isto, prossegue-se com a seção que trata especificamente dos mecanismos de suspense nas obras de ficção.

\section{MECANISMOS DE ATRAÇÃO DO LEITOR/ESPECTADOR NA FICÇÃO - CLIFFHANGERS}

No atual contexto pós-moderno, não se pode fugir do imediatismo e do excesso de informação que os veículos comunicadores oferecem. Nesse sentido, a "briga" pela atenção do público é intensa, pois cada vez mais surgem canais, serviços, sites, plataformas, aparelhos, aplicativos e tantos outros produtos que competem pelo tempo acirrado de consumo da população. Por isso, é comum que sejam utilizados recursos que atraiam as pessoas, para que em meio a infinitas possibilidades elas possam escolher aquela que mais se destaca. E esse é um projeto constante, já que não basta ser escolhido; é preciso que esse público permaneça consumindo e divulgando tal produção. Nas narrativas, dentre várias ferramentas, uma das mais surpreendentes é o cliffhanger.

O termo cliffhanger é geralmente definido como um recurso de construção de suspense nas produções fictícias. Literalmente, significa "à beira do precipício", mas o significado é relacionado ao sentido conotativo da expressão, ou seja, o cliffhanger é um mecanismo que induz à sensação de aflição, de expectativa pelo que está por vir na história. Por provocar uma sensação de tensão e drama no público, essa ferramenta narrativa acaba atraindo a atenção do leitor ou espectador para que continue acompanhando a continuação da história, seja o próximo capítulo de um livro, o próximo episódio de uma série, a sequência de um filme, etc., como a prática comumente denominada binge-watching, que significa basicamente "maratonar" uma série, assistir compulsivamente e quase sem pausa.

Deste modo, o cliffhanger é mais usualmente aplicado ao final das partes de uma obra ou dela própria, e tem sido cada vez mais importante para a conquista do público numa era de massiva produção de séries, filmes, programas, jogos e histórias para a TV, plataformas virtuais de streaming, videogames, smartphones e para o meio literário. Assim, esse mecanismo permite o encanto do público não só para permanecer assistindo, lendo ou jogando durante a execução dessas obras, mas também podem fazer com que mantenham-se esperando pelas sequências, que comentem sobre o que consumiram uns com os outros e consequentemente divulguem mais e mais essas produções (HARVEY, 2019).

Utilizado na TV para manter o público atento nos intervalos comerciais, nos finais de semana e nas pausas entre um episódio e outro e entre temporadas (NARANJO; FERNÁNDEZ-RAMÍREZ, 2020), o cliffhanger permanece com funções parecidas no que se refere às séries lançadas em plataformas de streaming, como é o caso de $O$ conto da aia (2017). Em algumas plataformas, as séries são disponibilizadas completas em um único dia, mas no caso da série analisada na presente pesquisa, 
as temporadas de lançamento oferecem um episódio por semana, num sistema parecido com o dos canais de televisão.

Vale ressaltar que depois de lançada uma temporada, todos os episódios ficam disponíveis de modo ilimitado, assim como em outras plataformas e para demais produções, mas o cliffhanger mantém o propósito de incitar o consumo contínuo (maratona) e o interesse do público, principalmente porque o conteúdo pode ser assistido a qualquer hora e em qualquer lugar, online ou offline.

Assim, sustentar-se por cliffhangers é essencial para a série $O$ conto da aia, porque além da pausa semanal entre cada capítulo, os serviços de streaming permitem o acesso, a qualquer momento, aos episódios e temporadas já lançados. Assim, ao mesmo tempo em que isso dá autonomia para o público assistir quando e onde quiser, pode também resultar no adiamento do consumo imediato, que é essencial para entender o nível de audiência da série, necessário para sua manutenção e continuidade. É uma via dupla que, até o momento, tem levado sucesso à produção, mas que corre o risco de sofrer um declínio se não houver novas estratégias de atração, das quais a mais significativa é o suspense, que será apresentado a seguir.

\section{O SUSPENSE EM O CONTO DA AIA (1985)}

A romance distópico $O$ conto da aia mescla uma sociedade opressora, a supervigilância da população, a falta de liberdade (especialmente para as mulheres) e ideais teocráticos numa narrativa densa e complexa, caracterizada pelo intimismo e subjetividade da protagonista, Offred. Essa personagem não tem muito o que fazer além de pensar, lembrar do passado, conspirar sobre estranhezas de sua rotina e realizar seu "destino" como aia, o qual consiste em deitar-se uma vez por mês sobre a Esposa da família que a abriga e ser estuprada pelo Comandante, para tentar gerar um filho para eles.

Por isso, esse livro não possui muita ação ou conflitos que levam a grandes tensões: o leitor possivelmente não se sente inquieto, preocupado ou ansioso como se estivesse lendo uma história de terror ou de aventura, por exemplo. O trabalho de Margaret Atwood nessa produção é baseado numa construção contínua e minuciosa de horror, medo, choque, expectativa, esperança e dúvida, que culmina num final grandioso, ambíguo e incerto. Em razão disso, analisar a estruturação do suspense em $O$ conto da aia pressupõe explicar, mesmo que brevemente, as pequenas ocorrências que se interligam para um desfecho inesperado, que possivelmente deixa seus leitores boquiabertos ou, pelo menos, angustiados.

Dado o gênero desse romance, violência, injustiça e desigualdade são características quase essenciais no enredo da história, principalmente porque esta é contada do ponto de vista de uma personagem que faz parte do grupo mais oprimido nesse novo ambiente: as Aias. Nesse sentido, já é de se esperar que a qualquer momento ocorra alguma situação envolvendo tortura, punição ou morte. 
O suspense permeia a narrativa, e o leitor que a busca provavelmente já aguarda por acontecimentos que o surpreendam, de certa maneira. Contudo, por vezes a história posterga o cliffhanger, que não está presente em todos os finais de capítulo e nem mesmo em todos eles, mas se manifesta consideravelmente.

Verifica-se que os artifícios de reviravolta aparecem, em especial, através das descobertas de Offred, como a lembrança de que a Esposa de seu novo posto era uma antiga cantora da igreja (Capítulo três). As sutis mudanças de comportamento nas pessoas de seu convívio - a piscadela de olho que o motorista Nick lhe dá em certo dia (Capítulo quatro); o flagra que ela dá no Comandante próximo de seu quarto (Capítulo oito) - e o encontro da mensagem gravada secretamente no armário pela aia anterior: nolite te bastardes carborundorum (Capítulo nove). De forma gradativa, as revelações se tornam maiores, e novos acontecimentos se unem a esses pequenos atos ilegais, de rebeldia e de revolta. É como um efeito em bola de neve, que cresce até atingir o ápice nos últimos capítulos.

No caso do lampejo que tem sobre a antiga identidade de Serena Joy, Offred narra gradativamente tudo o que vê e o que lhe acontece: aos poucos, prepara o leitor para a grande descoberta, vai deixando pistas, como quando diz "Tive a impressão de reconhecê-la; ou pelo menos algo de familiar nela" (ATWOOD, 2017, p. 24), descrevendo vagarosamente toda a cena para, no final, concluí-la com “A mulher sentada na minha frente era Serena Joy. Ou tinha sido, outrora. De modo que a situação era pior do que eu havia imaginado" (ATWOOD, p. 26). O leitor recebe uma informação importante que lhe dá a certeza de que algo complexo irá acontecer, mas também o suspense do que será, como e quando.

A mesma estratégia se repete na situação em que Nick flerta com Offred, no flagra do Comandante, na descoberta da frase secreta da antiga aia; o recurso é utilizado também em outras revelações e momentos. Por isso, a narrativa é demoradamente descritiva, reflexiva e combinada por presente e passado; ainda que ao final se revele que a história não passa de uma gravação póstuma encontrada por pesquisadores, tudo é contado como se acontecesse no exato momento em que se lê, o que possivelmente contribui para o suspense e a incerteza de qual o final, do que aconteceu.

Ademais, a temática de $O$ conto da aia é incômoda, diferindo-se de muitos clássicos da distopia ao abordar o abuso sexual, a violência física explícita, as mortes cruéis e normalizadas que aparecem ocasionalmente no decorrer da história. Também o viés religioso pode ser um ponto problemático, que mesmo desfigurado talvez seja constrangedor para certos públicos. Tudo isso somado a uma narrativa arrastada, que se demora em detalhes e reflexões, manipula a ansiedade do leitor em uma conjunção de etapas, e se tenta afetá-lo de maneira mais psicológica que física e imediata, talvez não seja o tipo de produto mais fácil de ser consumido por um público receptor de uma era pós-moderna. 
A dificuldade não está na obra em si ou no leitor que com ela não se identifica tanto: existe, nesse caso, uma diferença entre a obra e o receptor de determinada era ou cultura, nesse contexto, a contemporânea, mas isso não é nenhuma regra. O que se pretende apontar neste estudo está relacionado à adaptação do livro, uma tentativa de traçar as características da utilização do suspense e como isso contribui para o sucesso da série de streaming. Novamente, a intenção não é comparar ou sobrepor uma obra à outra como superior, mas entender a ocorrência de ferramentas de suspense em ambas.

Isto posto, observa-se que $O$ conto da aia produz o suspense utilizando principalmente a memória, que contribui tanto para o desenvolvimento das descobertas de Offred - tomada como central para essa análise, porque todos os acontecimentos giram em torno da história dela, no tempo e espaço determinados pelo livro - como também é retomada para protelar as reviravoltas, as resoluções de conflitos e as respostas para as dúvidas levantadas ao longo do enredo. Assim, gradualmente a memória vai revelando quem é quem, quando a identidade dos personagens é importante, e ainda o que aconteceu até que a República de Gilead se tornasse o que é. O passado faz relações com o presente.

\subsection{O SUSPENSE EM O CONTO DA AIA (2017)}

A série $O$ conto da aia se consagrou como uma das produções mais populares do serviço de streaming Hulu, mas está disponível no Brasil através dos serviços Paramount+ e Globoplay. Foram diversos prêmios e indicações, mas a recepção do público é uma das principais evidências do sucesso de execução e transmissão dessa obra. Desse modo, entender a construção e recepção do suspense implica especialmente uma análise dessa série, que popularizou a história para além do consumo massivo, motivando também muitas pesquisas e ainda promovendo grande procura pelo livro. (ANDRADE, 2020; SOMACARRERA-ÍÑIGO, 2019)

Um rápido olhar para a série faz notar que, em relação à história do livro, existe a mudança na ordem de certos acontecimentos, a ampliação e transformação de alguns e ainda o acréscimo de outras características. Isso já atesta que certas escolhas, não necessariamente em comparação com as do livro, são posicionadas e reposicionadas como estratégia para basear a história de $O$ conto da aia (2017) em algo cheio de suspense, certo terror e bastante ação e tensão. Cabe ressaltar que isso ocorre em conjunto com outras estratégias da narrativa audiovisual: imagens, posicionamentos de câmera e trilha sonora são apenas algumas percebidas superficialmente.

Tais decisões são, conforme artigo de Pilar Somacarrera-Íñigo, essenciais para o processo de adaptação da série e, em consequência, estão relacionadas ao poder representativo da mídia utilizada combinado ao poder da narrativa (SOMACARRERA-Í̃̃IGO, 2019). Significa, então, que para além de contar a história - como o livro faz -, a série utiliza os elementos próprios do veículo audiovisual para tornar tudo mais expressivo, resultando em algo ao mesmo tempo objetivo e com novas 
subjetividades que substituem ou se unem às apresentadas pela obra literária, o que acaba por atrair e aproximar mais o público contemporâneo.

A composição do suspense na série $O$ conto da aia também se baseia numa construção de pequenos atos, que vão se expandindo e se reunindo numa grande atividade de reação - de resistência - à situação em que os principais personagens estão inseridos. O primeiro episódio, por exemplo, intitulado "Offred", tem diversas situações de tensão consideravelmente profundas e relevantes para o decorrer da trama: no começo, o espectador acompanha a perseguição que a protagonista enfrenta com sua família, ao tentar fugir do novo governo; obviamente, ela não consegue, mas é oferecida, para quem assiste, a expectativa/esperança de que dê certo.

No mesmo episódio há também alguns flertes da protagonista com o motorista Nick, a revelação de que a companheira de compras, Ofglen, faz parte da resistência, e ainda a descoberta de que há um Olho, um espião do governo, na casa em que Offred vive. A última cena, que fica de gancho para o capítulo seguinte, é relacionada justamente a essa descoberta mais recente. Identifica-se, a partir disso, como a estrutura dos capítulos é desenvolvida com cliffhangers que prendem a atenção do espectador do começo ao fim, e que são, por sinal, ligados a atitudes ousadas, perigosas, para causar o medo do que pode acontecer aos personagens e a esperança de que tudo dê certo, de que esses personagens continuem se rebelando para se livrarem de tal situação.

A inserção dos cliffhangers descritos acima relaciona-se estreitamente com as ideias defendidas pela Estética da Recepção: dentre várias técnicas da narrativa escrita e audiovisual, tal ferramenta de suspense depende da relação da obra com o público, mais especificamente baseia a estrutura da história na provocação de sentimentos no espectador, como apresentado por Jauss (2011a) anteriormente, a respeito do efeito e da recepção de uma forma artística. Muito além do que entregar o conteúdo, a série $O$ conto da aia divide a construção da ficção com o leitor, e por mais que seja pré-produzida necessita da aceitação e demanda do público por mais episódios e temporadas, o que possivelmente não seria tão bem executado se não houvesse esse processo de troca.

O mesmo se repete nos episódios seguintes, de certa maneira. No episódio "Birth day" (Dia do nascimento), um dos cliffhangers mais angustiantes de toda a temporada é quando Offred, feliz por estar dividindo segredos com o Comandante, pretende contar para a amiga Ofglen sobre o que aconteceu na noite passada, mas quando chega ao portão descobre que ela foi substituída por outra aia, a qual aparentemente é uma alienada, que se nega a dar informações. O episódio termina com a dúvida: o que houve com a antiga Ofglen e o que acontecerá em seguida? Assim, provoca-se no espectador o suspense para continuar esperando pelo próximo capítulo ou para assisti-lo, caso já esteja disponível.

Diferentemente do que acontece com o episódio anterior, o terceiro, intitulado "Late" (Atrasado), começa já resolvendo o conflito iniciado na cena final de "Birth day", que é o sumiço da 
antiga Ofglen. Portanto, o terceiro episódio começa com ela sendo levada para um julgamento pelo fato de ter mantido um relacionamento homoafetivo em segredo com outra mulher. Offred, que tinha a possibilidade de estar grávida, acaba perdendo o bebê por causa da agressão sofrida no interrogatório sobre Ofglen. E por fim, Emily - a antiga Ofglen - descobre que teve seu clitóris removido como punição. É um episódio cheio de dúvidas não sanadas, que se mescla com flashbacks das reações da população da história diante do novo governo. Ele se finaliza sem um grande cliffhanger, de forma bem trágica, na verdade. Existe apenas a expectativa de que algo muito ruim ou muito bom está por vir.

Quanto a esse aspecto, pode-se aproximá-lo do que é exposto na seção 2 sobre a imersão do indivíduo enquanto contempla uma produção artística (JAUSS, 2011b): são infinitas as possibilidades de assistir e interpretar a série $O$ conto da aia, e o sujeito pode escolher sentir prazer de forma externa à obra. Contudo, é possível e natural que nesse processo o público projete seu contexto individual, que se utilize da arte para entender a si mesmo, o que não necessariamente implica uma prática complexa de reflexão ou pensamento (JAUSS, 2011b). Apreciar as sensações e os efeitos da série no próprio ser é suficiente para demonstrar quão intensa é a relação entre obra e público.

O sexto episódio - “A woman's place" (O lugar de uma mulher) - retoma os finais de reviravolta que não foram tão utilizados no quarto e no quinto episódios. Com uma visita de diplomatas de outros países, um dos acompanhantes revela a Offred que o marido dela está vivo e lhe diz que ela pode enviar uma mensagem a ele. Isso representa um grande conflito na vida da protagonista, que acabara de começar um relacionamento secreto com o motorista Nick, e também a esperança de poder fugir de tal situação, porque é a primeira notícia de que existe alguém que ela conhece fora da República de Gilead. Com esse cliffhanger, o espectador é convidado a retomar a expectativa, de certa forma minguada pela sucessão de acontecimentos ruins na trama, de que há possibilidade para um final bom. $\mathrm{O}$ episódio sete, "The other side" (O outro lado), por sua vez, explana justamente o que aconteceu com o marido de Offred, Luke, através de flashbacks que mostram como ele foi pego e também momentos presentes que levam até a chegada do bilhete da esposa para ele, já no Canadá.

Em “The bridge" (A ponte), os momentos de tensão retornam especialmente através da tentativa de suicídio da personagem Janine com sua filha recém-nascida, Charlote. Offred consegue convencêla a entregar a criança, mas mesmo assim a moça se joga, porém sobrevive, como é mostrado algumas cenas depois. É um acontecimento complexo e angustiante, que gera falta de esperança, ao mesmo tempo em que permite pensar que a personagem finalmente estará livre, mas como ela é salva, o pesadelo continua, assim como a expectativa pelo que acontecerá futuramente. Além disso, Offred consegue pegar o pacote secreto que o movimento de resistência Mayday lhe pedira, e a personagem 
Moira mata um dos "clientes" da casa de prostituição e entra no carro dele, deixando esse cliffhanger de expectativa pelo que lhe acontecerá para o próximo episódio.

Esse momento da trama se associa aos argumentos de Iser (2011) acerca do jogo do texto - ou seja, nesse caso pode-se analisar o trabalho do autor ao fazer referência a um acontecimento e deixar que o espectador o imagine, interprete e concretize, de certo modo. Com essas conclusões abertas e ganchos (o que ocorre, inclusive, no episódio final), a série não somente promove sentimentos diversos no público, como também o convida a questionar e presumir o que acontecerá na sequência do enredo, e essa dúvida e expectativa também movem o espectador a continuar assistindo ou esperando pelo próximo episódio ou temporada, mesmo que já esteja disponível ou o lançamento ainda demore um ano.

O último episódio da temporada, "Night" (Noite), é repleto de tensão, visto que esclarece muitos dos cliffhangers introduzidos ao longo da série, para finalizar a primeira parte. Assim, existe, por exemplo, o momento em que Serena confronta Offred após descobrir sobre os encontros secretos da aia com o Comandante, seguido da revelação que June está grávida. Também é mostrada a chegada de Moira ao Canadá, seu reencontro com Luke e a tentativa que Tia Lydia faz de incitar o linchamento de Janine, mas as Aias reagem e não fazem nada. O encerramento do capítulo mostra Offred sendo encaminhada para uma caminhonete, mas ninguém sabe o motivo; apenas a suposição de que ela será punida por não ter matado Janine.

Novamente, nesse caso, há o final ambíguo, incerto. A maioria dos cliffhangers e questionamentos levantados, pouco a pouco, ao longo dos demais episódios são, de certa maneira, resolvidos e explicados nesse último capítulo. Mas como a estratégia da série é o uso de cliffhanger, novamente levanta-se a dúvida sobre o que ocorrerá a seguir, sempre em contínua tensão e angústia. As respostas, contudo, estarão na temporada seguinte. Nessa direção, a introdução de Ariane Hudelet, no artigo "Dealing with Long Duration: TV Series, Aesthetics and Close Analysis" ("Lidando com longa duração: séries de TV, estética e análise atenta”), sustenta o que foi argumentado:

Embora as séries também sejam marcadas por uma forma de interrupção por causa de seu caráter episódico, sua principal característica, no entanto, é a duração muito longa e a capacidade de envolver os espectadores por muitas horas - às vezes durante vários meses e, esperançosamente, ao longo de muitos anos. Os espectadores [...] dedicam partes substanciais de suas vidas a essas ficções e se envolvem emocional e intelectualmente com essas narrativas e personagens cada vez mais complexos [...]. (HUDELET, 2020, p. 1)

Assim, evidencia-se na série uma condensação dos momentos mais ativos da história, a inserção de novas situações de tensão e a reunião de cenas que se combinam em conflitos consecutivos, construídos e esclarecidos por meio da união de flashbacks e acontecimentos do presente (na história). 
Com isso, verifica-se a utilização de cliffhangers principalmente nos momentos finais de cada episódio, como convite para que o espectador não abandone a série, isto é, para que continue esperando pelo próximo capítulo ou temporada.

Esse mecanismo de suspense é efetuado, obviamente, pelo espectador, que é determinado pela narrativa a se apegar a certos personagens e a repugnar outros, para que assim a expectativa de melhorias seja sentida, assim como a tensão, a dúvida e o medo comandem-no a continuar acompanhando tudo até o fim, como se inserido em tal mundo fictício.

\section{CONSIDERAÇÕES FINAIS}

$\mathrm{Na}$ atual era pós-moderna de numerosas produções culturais e simultâneo consumo, o trabalho de análise de qualquer produção artística implica, mais do que nunca, um olhar para o público, que passou de um seleto grupo de contemplação da arte para a razão de existência desta. Nesse sentido, os estudos de Estética da Recepção ajudam a clarificar e delinear a importância dos receptores do texto enquanto parte dessa construção, sem os quais as intenções do autor e as manifestações destas na materialidade não seriam efetuadas, movidas, significadas.

A escolha de duas produções de uma mesma história - $O$ conto da aia livro e série - foi um exemplo da execução de um dos mecanismos mais populares de atração do leitor/espectador de ficção: o suspense como instrumento manipulativo psicológico de angústia e expectativa, que, ao mesmo tempo que provoca sensações ruins, motiva o público a permanecer inserido na história para esperar pela resolução dos problemas. Através principalmente do cliffhanger, essas duas narrativas sobrepõem lentamente pequenas situações conflituosas que chegam ao ápice no final do livro e da temporada. Isso evidencia, no fim das contas, o quão bem-sucedidas são as duas produções no uso desse recurso, cada uma à sua maneira.

Tal êxito foi notado, em especial, com a popularização de ambas as obras a partir do lançamento da série em 2017, conforme demonstra pesquisa de Felipp Andrade sobre a recepção dessas duas obras (ANDRADE, 2020). Assim, propõe-se que a adaptação, mesmo considerada aqui de forma independente, colabora até o momento com a divulgação da história, que já se encontra na quarta temporada. Para mais, acredita-se que, em consequência, o livro tenha ganhado uma continuação mais de trinta anos depois de sua publicação, visto que essa trama foi reavivada e, portanto, permanece pertinente nas discussões sobre temas necessários como o machismo, a misoginia e a ascensão de grupos conservadores no contexto político e social de alguns países.

Em suma, reafirma-se a importância de histórias como essas, que têm no suspense não só uma ferramenta de promoção do consumo massivo e instantâneo, mas, conforme as ideias de Jauss (2011a), também incitam no público um processamento do conteúdo recebido, de forma a aplicá-lo à realidade, 
para então se pensar criticamente sobre os rumos dessa e das próximas gerações no que se refere às crises ambientais, sociais, econômicas e biológicas. 


\section{REFERÊNCIAS}

ALWARD, P. Cliffhangers and Sequels: Stories, Serials, and Authorial Intentions. Dialogue, v. 57, n. 1, p. 163-172, 2018.

ANDRADE, F. A. T. Recepção literária e mídias: uma breve análise de The Handmaid's Tale. Estação Literária, v. 24, n. 1, p. 88-98, 2020.

ATWOOD, Margaret. O conto da Aia. Trad. Ana Deiró. Rio de Janeiro: Rocco, 2017.

CARVALHAL, T. F. De traduções, tradutores e processos de recepção literária. Revista Brasileira de Literatura Comparada, v. 5, n. 5, p. 85-92, 2017.

GOMES, A. L.; PINHEIRO, M. M. F. Estética da recepção em suas bases conceituais. In: . A leitura da imagem na TV e a dinâmica da recepção em Hoje é dia de Maria. Natal, RN: EDUFRN, 2017.

HARVEY, C. The art of the cliffhanger. Writing Queensland, n. 266, p. 18-19, 2019.

HUDELET, A. Dealing with Long Duration: TV Series, Aesthetics and Close Analysis. InMedia. The French Journal of Media Studies, n. 8.1., 2020.

ISER, W. O jogo do texto. In: LIMA, L. C. A literatura e o leitor: textos de estética da recepção. SP: Paz e Terra, 2011, p. 105-118.

JAUSS, H. R. A estética da recepção: colocações gerais. In: LIMA, L. C. A literatura e o leitor: textos de estética da recepção. SP: Paz e Terra, 2011a, p. 67-84.

JAUSS, H. R. O prazer estético e as experiências fundamentais da Poiesis, Aisthesis e Katharsis. In: LIMA, L. C. A literatura e o leitor: textos de estética da recepção. SP: Paz e Terra, 2011b, p. 85-104.

NARANJO, A.; FERNÁNDEZ-RAMÍREZ, L. Cambios en la estructura narrativa de las series de Netflix. El caso de Mindhunter. ASRI - Revista de Investigación en Artes y Humanidades Digitales, $\mathrm{n}$. 18, p. 137-153, 2020.

O conto da Aia. Direção: Reed Morano. Produção: Bruce Miller, Warren Littlefield, Reed Morano, Daniel Wilson, Fran Sears, Ilene Chaiken, Margaret Atwood, Elisabeth Moss. Estados Unidos: Hulu, 2017.

SOMACARRERA-ÍNIIGO, P. "Thank you for creating this world for all of us": globality and the reception of Margaret Atwood's The Handmaid's Tale after it's television adaptation. Revista Canaria de Estudios Ingleses, n. 78, p. 83-95, abril 2019.

TOLOMEI, C. N. Dialogismo, reescritura, recepção: apontamentos teóricos. Afluente, v. 2, n. 5, p. 150-164, mai./ago. 2017. 